\title{
Afrorrománico, iberorrománico y orígenes del español
}

Resumen: El área de estudio de la Filología Románica comprendía en su origen las provincias romanas de Africa, Numidia y Mauretania, como parte de una Romania submersa, territorios donde el latín había dejado de hablarse en un cierto tiempo por diversos factores históricos, sobre todo migraciones. Entre los siglos VI y X d. C. se produce un gran cambio lingüístico en el Mediterráneo occidental al que puede añadirse otro cambio de perspectiva, porque la eusquerización de los territorios considerados vascos tradicionalmente se produjo como consecuencia de la migración del siglo VI. La bibliografía tradicional obviaba o marginaba aspectos esenciales que la investigación de los últimos veinte años ha reforzado. Entre ellos hay que destacar la situación del latín en África e Hispania, que incluye el latín de los invasores bárbaros. También debe precisarse cuál era la situación lingüística de los bereberes y qué lengua hablaban los invasores de Hispania el 711. Los puntos que hay que tener en cuenta son: (1) el bilingüismo en la Hispania romana, en la Mauretania y en África, (2) la lengua vasca como lengua del Bajo Imperio en su área de Hispania, (3) la lengua de visigodos y vándalos, (4) bereber, romance y árabe en el Magreb, (5) el afrorrománico de los bereberes en Al-Andalus y (6) romance andalusí, vasco-románico e iberorrománico en los orígenes del español. Al norte de Alandalús se produjo un contacto de afrorrománico, iberorrománico (también romance andalusí) y vascorrománico, además de otras situaciones de bilingüismo, cuya valoración obliga a redefinir los orígenes del español.

Palabras clave: Romania submersa, afrorrománico, bereber, latín tardío, vasco

La Arqueología proporciona a los investigadores que quieren sumergirse en ella nuevos textos y nuevas perspectivas. Los descubrimientos arqueológicos, sin duda, han tenido una influencia muy clara en el desarrollo de una nueva filología del latín africano. Desde el punto de vista teórico, los lingüistas comienzan hoy con aproximaciones que no se limitan a la división entre lenguas, dialectos, haces dialectales, bilingüismo o diglosia. La teoría de la variación y la necesidad de tener en cuenta las variantes han aportado nuevos significados a la terminología tradicional, sin que ello implique perder siempre los anteriores. En lo que

Francisco A. Marcos-Marín, University of Texas at San Antonio 
concierne a los textos, hay que tener en cuenta los escritos dentro de los registros cultos, como los literarios, históricos, teológicos o epigráficos, junto con cuantos reflejan lo que a veces parecen casi criollos del latín y otras lenguas africanas. La arqueología ha proporcionado un número amplio de textos de ese segundo tipo; ${ }^{1}$ pero también cabe hacer nuevos análisis y mejores interpretaciones de los del primero.

Las actas de venta denominadas Tablillas Albertini fueron descubiertas en 1928, lo que ha permitido su estudio detenido, especialmente por Väänänen en $1965 .^{2}$ Ahora se puede ampliar con el de los nuevos textos latinos, como los ostracones argelinos de la región de Bir Trouch, dados a conocer por Bonnal y Février, ${ }^{3}$ las series sucesivas de los conocidos como los ostracones de $\mathrm{Bu}$ Njem, descubiertos por René Rebuffat en las excavaciones de Golas, Tripolitania, como explicó Marichal. ${ }^{4}$ Los ostracones, recuérdese, están escritos generalmente sobre fragmentos de cerámica e incluso de revoque de muro. Ya Marichal se preguntaba si el tipo de latín empleado en los ostracones, más que un latín vulgar, no podría reflejar algún tipo de criollo o sabir. Este tipo de documentos se encuentra en otros lugares del Imperio, como las tablillas de madera escritas en tinta de una fortificación romana próxima al Muro de Adriano, en el norte de Inglaterra, descubiertas a partir de 1973, o los más de diez mil ostracones descubiertos en el desierto oriental de Egipto, Mons Claudianus, en los años 1980 y $1990 .^{5}$ Las Tabellae Albertini (que todavía pueden estudiarse con provecho) y los muy abundantes textos descubiertos después, exigen una reinterpretación de la conexión

1 «North Africa», en Late Antique and Early Medieval Inscriptions, Mark Handley, 2010-2014 (página web) [fecha de consulta: 27-03-2016] <http://handley-inscriptions.webs.com/northafrica. $\mathrm{htm}>$.

2 Veikko Väänänen, Étude sur le texte et la langue des Tablettes Albertini, Helsinki, Suomalainen Tiedeakatemia, 1965.

3 J. P. Bonnal y Paul Albert Février, «Ostraka de la région de Bir Trouch», en Bulletin de l'Archéologie Algérienne, 2 (1966-1967), pp. 239-249.

4 Véase Robert Marichal, «Les ostraca de Bu Njem», en Comptes rendus des séances de l'Académie des Inscriptions et Belles-Lettres, 123.3 (1979), pp. 436-452, más recientemente reeditados como Les Ostraca de Bu Njem, (Libya Antiqua, supplément VII), Tripoli, Grande Jamahira Arabe/ Libyenne, 1992.

5 Publicados por Jean Bingen et al., Mons Claudianus, Ostraca graeca et latina II, O.Claud. 1 à 190, Cairo, Institut Français d'Archéologie Orientale, 1992; Jean Bingen et al., Mons Claudianus, Ostraca graeca et latina II, O.Claud. 191 à 416, Cairo, Institut Français d'Archéologie Orientale, 1997; Hélène Cuvigny, Mons Claudianus. Ostraca Graeca et Latina III. Les reçus pour avances à la familia (O.Claud. 417 à 631), Cairo, Institut Français d'Archéologie Orientale, 2000, y Adam Bülow-Jacobsen, Mons Claudianus. Ostraca Graeca et Latina IV. The Quarry-Texts (O.Claud. 632-896), Cairo, Institut Français d'Archéologie Orientale, 2009. 
entre el latín y el bereber, esencial para comprender el papel lingüístico representado por los bereberes en Alandalús.

La idea de la variación en latín, especialmente en latín africano, tuvo que esperar hasta el año 1998, cuando la reformuló Petersmann en Madrid, ${ }^{6}$ basándose en principios lingüísticos y no estilísticos, con ejemplos tomados de textos como la versión bíblica conocida como Vetus Latina Africana y el C.I.L. Contribuyó a la nueva perspectiva un mejor conocimiento del bilingüismo latino, gracias a los trabajos de Adams a partir de 2003.' Investigaciones posteriores, como las del autor de esta ponencia, han mostrado la situación del latín en relación con el líbico bereber y el púnico. ${ }^{8}$ Desde 2015 el autor ha presentado contribuciones necesarias para revisar en profundidad lo que (no) se suponía acerca del bilingüismo de los hablantes de latín y lo que se consideraba consabido acerca de los vascos, visigodos, vándalos, bizantinos, bereberes, ibero-románico y afro-románico, con énfasis especial en la situación de Mauretania Tingitana entre los siglos IV y VIII o en Alandalús, sobre todo en el norte, en los siglos VIII y IX. ${ }^{9}$

Esas investigaciones han aportado datos suficientes (no meras hipótesis) para demostrar que en 711 en el norte de África la generalidad de los hablantes usaba un continuo bereber-latino, que contaba con entre siete y nueve siglos de antigüedad y en el que, como en todas las estructuras de ese tipo, la oscilación

6 Hubert Petersmann, «Gab es ein afrikanisches Latein? Neue Sichten eines alten Problems der lateinischen Sprachwissenschaft», en Benjamín García-Hernández (ed.), Estudios de Lingüística latina. Actas del IX Coloquio Internacional de Lingüística Latina, Madrid, Ediciones Clásicas, 1998, pp. 125-136.

7 James Noel Adams, The Regional Diversification of Latin $200 B C-A D$ 600, Cambridge/New York, Cambridge University Press, 2003; Bilingualism and the Latin Language, Cambridge/New York, Cambridge University Press, 2007, y Social Variation and the Latin Language, Cambridge New York, Cambridge University Press, 2013.

8 Francisco Marcos Marín, «Notas sobre los bereberes, el afrorrománico y el romance andalusí», en Hesperia Culturas del Mediterráneo, 19 (2015), pp. 203-221; «Latín, beréber, afrorrománico, iberorrománico y romance andalusí. Interacción, desaparición y pervivencia de lenguas», en Revista Iberoamericana de Lingüística, 10 (2015), pp. 33-91; «Los posibles contactos africanos del romance andalusí», en Constance Carta, Sarah Finci y Dora Mancheva (coords.), «Antes se agotan la mano y la pluma que su historia»/ «Magis deficit manus et calamus quam eius hystoria». Homenaje a Carlos Alvar, San Millán de la Cogolla, Cilengua, 2016, vol. 1, pp. 199-216; «Las fronteras del latín africano», en Actas del X Congreso Internacional Estudios de Frontera, homenaje a Pedro Martínez Montávez, Alcalá la Real 5-6 junio 2015, Alcalá la Real, Diputación Provincial de Jaén, 2016, pp. 251-266; «La recepción de la literatura latina en Hispania y su repercusión en la literatura hispánica», en Stylos, 25 (2016), pp. 147-169, y «Latín africano, bereber, vándalos y visigodos», en Revista Iberoamericana de Lingüística, 11 (2016), pp. 173-208.

9 En general, se encontrarán detalles y ampliaciones de lo enunciado en este trabajo en los ya citados «Latín, beréber, afrorrománico, iberorrománico y romance andalusí. Interacción, desaparición y pervivencia de lenguas» $\mathrm{y}$ «Latín africano, bereber, vándalos y visigodos». 
hacia el bereber o hacia el latín dependía de las condiciones diglósicas, del conocimiento de las lenguas por los hablantes, del contexto sociolingüístico y otros factores conocidos que regulan la conmutación de códigos. El latín en el Norte de África seguiría todavía durante siglos su lento proceso de evolución en afrorrománico y desuso y al final, arrinconado entre el árabe magrebí y las hablas bereberes, terminaría por perderse, tras dejar huellas todavía por estudiar. El estudio de las variantes del afrorrománico en Alandalús y el contacto entre esas variantes y el iberorrománico requiere más atención y, sobre todo, precisión técnica, de la que se encuentra en los trabajos de Oliver Asín. ${ }^{10}$ El conocimiento general del romance andalusí se beneficia del mayor conocimiento posible del árabe andalusí que ha hecho posible la investigación de Federico Corriente. ${ }^{11}$ En cualquier caso, el contacto entre el árabe y las lenguas romances merece una mayor atención y requiere nuevos planteamientos, como ha señalado, especialmente, María Jesús Viguera. ${ }^{12}$ La diferencia entre «mozárabe», denominación religiosa y cultural, y «romance andalusí», término lingüístico, ha sido establecida con claridad. ${ }^{13}$ Sería muy útil adecuar la terminología a esa delimitación más rigurosa, pero hay que contar con el peso de la tradición. El romance andalusí no era una lengua o una serie de dialectos hablados por los mozárabes (cristianos). Lo natural es suponer que, al menos durante las primeras cinco décadas de la conquista islámica, la mayoría de los hablantes, tanto cristianos como musulmanes, sabrían poco o nada de árabe y usarían las variantes románicas. Los testimonios históricos, escritos por los musulmanes vencedores, incluyen referencias claras a la continuidad de las variedades del latín en Alandalús. Después de la conquista musulmana, un número creciente de hablantes, la mayoría hombres, al menos inicialmente, aprendieron árabe, la lengua introducida por los nuevos conquistadores y las hablas romances en territorio musulmán fueron desapareciendo. El estudio de los contactos lingüísticos demuestra que un cambio completo de lengua se produce en un proceso trigeneracional. El árabe no era la única lengua llevada a Hispania por los conquistadores, el bereber tenía también su papel. Para el desarrollo del iberorrománico, empero, lo que importa es la presencia

10 Jaime Oliver Asín, En torno a los orígenes de Castilla. Su toponimia en relación con los árabes y los beréberes, Madrid, Real Academia de la Historia, 1974. Con índices en Al-Andalus, 38.2 (1973), pp. 319-391.

11 Federico Corriente, A Descriptive and Comparative Grammar of Andalusi Arabic, Leiden/ Boston, Institute of Islamic Studies of the University of Zaragoza/Brill, 2013.

12 María Jesús Viguera Molins, «Lengua árabe y lenguas románicas», Revista de Filología Románica, 19 (2010), pp. 45-54.

13 Puede verse mi «Romance andalusí y mozárabe: dos términos no sinónimos», en Estudios de Lingüística y Filología Españolas. Homenaje a Germán Colón, Madrid, Gredos, 1998, pp. 335-341. 
de distintas variedades de las variantes proto-románicas. Los invasores llevaron a Alandalús el continuo lingüístico latino o afrorrománico que, en África, había sobrevivido a los vándalos, como ha estudiado, especialmente Francovich Onesti, con el apoyo del cristianismo y el Imperio de Oriente y había permanecido entre los Mauri, incluso en territorios desguarnecidos militarmente por Roma, como la Mauretania Tingitana. Abandonados por Roma, pero no por la Romania.

El latín, al menos como lengua escrita norteafricana, subsistió de algún modo, probablemente limitado, hasta el siglo XI. Cuando los moros (<lat. Mauros) o bereberes iniciaron la conquista de la Hispania visigótica, salieron de Ceuta (Septem), una ciudad entonces bizantina donde se hablaba latín. También se hablaba en lo que hoy es Tánger (< [Maure]tanja), así como en las provincias romanas Caesariensis (Argelia) y Africa (Túnez). A esos moros invasores siguieron pronto hablantes de árabe y todos ellos fueron llamados «moros» en las lenguas iberorrománicas. Moros caracterizados después como hablantes de «algarabía» (< al- ${ }^{c}$ arabiyya 'árabe'). El latín hispánico se reconfiguró como lenguas romances distintas, todas las cuales tomaron elementos del árabe, pero también del bereber y del afrorrománico. El campo de investigación es amplio y sigue abierto.

Los musulmanes llegaron a la Península Ibérica desde el este, Siria o Yemen, o desde el oeste, la franja norte del África romana. Hablaban diferentes lenguas y variantes de éstas. Lo que encontraron cuando conquistaron la mayor parte de Hispania no es lo que se lee en las Historias de la Lengua Española. Y no se trata sólo de lo dicho a propósito del romance andalusí. Para los orígenes del español es mucho más relevante lo que hallaron al llegar a las tierras de La Bureba y los ríos Ebro y Duero. Esos invasores eran sobre todo bereberes, si bien algunos gobernantes de relieve, como los Banu Qasi (< Casius) en Zaragoza, eran de origen hispano. Los historiadores andalusíes informan de varias revueltas contra los gobernantes de Córdoba y el poder central musulmán inicial, árabe de modo predominante. Cualquier idea de una España Musulmana unificada inmediatamente después de la conquista daría lugar a graves confusiones, puestas de manifiesto por Zozaya.

Suevos, vándalos y alanos invadieron la Península el 411. Lo que hubo ocurrido después del año 411 fue mucho más que meras invasiones bárbaras. «Bárbaro», como término, es preferible a «germánico», porque no todos los invasores eran germánicos. Los alanos no lo eran. Durante mucho tiempo los romanos mantuvieron el control sobre la mayor parte de Hispania, con la ayuda de los visigodos, que tenían su capital en Tolosa (hoy Toulouse, Francia) desde 418. Hubo que esperar hasta 517 para que los visigodos, derrotados por los francos en Vouillé, fundaran su reino, con Toledo como su nueva capital, en los años 555-567. No unificaron Hispania hasta 625, cuando Suintila derrotó a los bizantinos en el sureste. Para entonces hablaban sobre todo o sólo latín y los restos de 
su lengua se limitaban a antropónimos (conservados también como topónimos) y algunos préstamos al latín.

El avance de los francos hacia el sur de la Galia a principios del siglo V tuvo consecuencias notables para el latín hispánico y los orígenes de las variantes o dialectos castellano y navarro. Forzó la emigración de la población vascohablante hacia el sur, desde Aquitania a Hispania. Hay que llamar aquí la atención sobre los estudios de González Ollé, incluyendo el muy extenso sobre la eusquerización, en $2016 .{ }^{14}$ La lengua vasca inició así su trasvase a Hispania, en una migración iniciada a principios del siglo VI d. C. Estos nuevos pobladores se establecieron entre las montañas al oeste de los Pirineos y el curso alto del río Ebro, con su límite meridional en La Bureba. En fecha tan temprana como 1925, ya Gómez-Moreno había advertido de que algunas palabras supuestamente vascas eran en realidad de origen celtíbero. ${ }^{15}$

El proceso, muy sintetizado, habría sido: la lengua vasca es una lengua pre-indoeuropea que estaba en uso desde la Edad de Bronce (antes de 1200 a. C.) en su territorio de procedencia. Este territorio era relativamente amplio y se situaba al norte de los Pirineos. A principios del siglo VI se había producido ya un desplazamiento de parte de esa población hacia el área de Pamplona, de donde se extendió hacia Vitoria y, desde allí, hacia el norte y el sur. Los préstamos de las hablas romances se presentan en todos los dialectos, lo que indica que se produjeron en el período medieval, a partir del siglo VI, y que la diferenciación dialectal del vascuence fue posterior. Como lo han explicado Abaitua y Unzueta:

El proceso de expansión es relativamente corto, acotable entre los siglos VI al XII, y en el que pueden concurrir diferentes dinámicas y acontecimientos que propiciaran movimientos de población (y de su lengua asociada); no debiéndose a un solo motivo histórico. Hechos como el repliegue visigodo a las tierras peninsulares tras la derrota de Vouillé (507), que tuvo que suponer el traslado de otros contingentes humanos asociados; las incursiones merovingias, francas y visigodas; la acción de la Iglesia; los levantamientos vascones, el origen y consolidación del reino de Pamplona; las políticas de repoblación medieval y otras fueron probablemente la causa múltiple del desplazamiento. ${ }^{16}$

En su avance hacia el sur, los vascohablantes llegaron más tarde a La Bureba, que se convirtió así en una frontera natural. Después de 711, con la llegada de los

14 Fernando González Ollé, «Navarra, Romania Emersa y ¿Romania Submersa?», en Aemilianense, 1 (2004), pp. 225-270, y muy especialmente «Vascones y vascuence. Historia (para romanistas) de una relación», en Revista Iberoamericana de Lingüística, 11 (2016), pp. 35-172.

15 Manuel Gómez-Moreno, "Sobre los iberos y su lengua», en Homenaje a Menéndez Pidal, Madrid, Hernando, 1925, vol. 3, pp. 475-499.

16 Joseba Abaitua Odriozola y Mikel Unzueta Portilla, «Ponderación bibliográfica en historiografía lingüística. El caso de la "vasconización tardía”», en Oihenart, 26 (2011), p. 24 y figura 3. 
bereberes, esa área pasó a ser también la frontera norte de los invasores musulmanes y el punto de confluencia entre los vascos más o menos latinizados, los hablantes de hispano-latín y los bereberes, hablantes de sus dialectos y también de los del latín africano. ${ }^{17}$ Esta situación afectó el desplazamiento de los bereberes. Detenidos en La Bureba, establecieron una línea de defensa en lugares que nombraron de modo que prueba su uso del latín. Como su avance hacia el norte quedaba cortado por los vascos y hacia el este por los Bani Qasi, los bereberes tuvieron que desplazarse hacia el oeste. Siguieron la línea del Duero donde encontraron hablantes de latín hispano y desarrollaron una cultura interesante hasta que se produjo la Reconquista del área por los cristianos, que asimilaron a los que permanecieron en la región.

La continuidad del latín en el noroeste de África entre los siglos V y X está bien atestiguada y la apoyan los nuevos estudios y descubrimientos. Cabe esperar mucho de la Arqueología y del análisis de los fondos de los museos magrebíes. El latín tardío se empleó en la producción de textos literarios hasta la llegada de los musulmanes; pero las inscripciones atestiguan un cierto uso de la lengua al menos hasta el siglo XI. Varios testimonios de autores árabes se refieren al uso de variedades del latín, quizás variantes románicas, hasta el siglo XII. El conocimiento del afrorrománico es limitado, por la ausencia de textos. Se conservan, por supuesto, muchos textos en diversos registros latinos; pero ninguno puede ser considerado romance. Hace falta un detenido estudio de los textos latinos, en busca de lo que pueda relacionarse con ejemplos de contacto lingüístico entre el afrorrománico, el sardo, los dialectos sur-itálicos y las lenguas ibero-romances, en particular el romance andalusí, el cual, desgraciadamente, tampoco proporciona muchos textos.

Se pueden definir algunos rasgos lingüísticos básicos del afrorrománico, pese a esa limitación de datos analizables por el momento, que no tiene por qué ser duradera. En esta recolección se seguirá el orden habitual de Fonología,

17 Son muchos los autores que han señalado este hecho. Del más antiguo al más moderno, una escala de fechas podría ser: el ya citado Jaime Oliver Asín, En torno a los orígenes de Castilla. Su toponimia en relación con los árabes y los beréberes; Juan Zozaya, «La arqueología del poblamiento islámico en Al-Andalus», en Boletín de Arqueología Medieval, 7 (1993), pp. 53-64; «Toponímia (sic) árabe en el valle del Duero», en Mario Jorge Barroca e Isabel Cristina F. Fernandes (eds.), Muçulmanos e Cristãos entre o Tejo e o Douro (Sécs. VIII a XIII). Actas dos Seminários realizados em Palmela, 14 e 15 de Fevereiro de 2003, Porto, 4 e 5 de Abril de 2003, Porto, Câmara Municipal de Palmela/Faculdade de Letras da Universidade do Porto, 2005, pp. 17-42, y «La Bureba ¿frontera islámica mediante colonización agraria?», en Francisco Toro Ceballos y José Rodríguez Molina (coords.), IX Estudios de Frontera. Economía, Derecho y Sociedad en la Frontera. Homenaje a Emilio Molina López, Alcalá la Real, Diputación Provincial de Jaén, 2014, pp. 871-881; María Jesús Viguera Molins, «Lengua árabe y lenguas románicas», y mis trabajos ya mencionados. 
Morfología y Sintaxis. Sin insistir más en ello por ahora, está claro que los poemas de $\mathrm{Bu}$ Njem confirman que el latín africano había perdido la cantidad vocálica como rasgo fonológico suprasegmental. Otros indicadores apuntan a la equivalencia de la cantidad y el acento prosódico en ciertas posiciones, lo cual hace pensar inmediatamente en fenómenos similares en las jarchas y cejeles andalusíes. Cuando San Agustín, en De doctrina christiana IV, 10, advierte al lector de que los africanos confunden fácilmente ōs, 'boca', con ŏs, 'hueso', lo que quiere decir es que no percibían la diferencia de cantidad vocálica. Por esa razón recomienda que los predicadores empleen ossum como acusativo singular del neutro ŏs, 'hueso' (que debería ser ŏs, como el nominativo). En respuesta a su propia pregunta, concluye «Afrae aures de correptione uocalium uel productione non iudicant» ('los oídos africanos no distinguen la longitud o brevedad de las vocales', 4, 10.24). Algunos ejemplos de préstamos latinos en bereber son cǐcer, 'garbanzo' > akiker, ikiker; fŭrca, 'horca' > afurk, tfurket; ŭlmu, 'olmo' > ulmu, tulmuts. Estos fenómenos y otros permiten establecer una relación con el latín de Cerdeña o Hispania que enlaza nombres como el clásico de Wagner, ${ }^{18}$ con autores actuales, como Lorenzetti y Schirru. ${ }^{19}$ No significa que el afrorrománico fuera a moverse hacia una solución vocálica similar a la del sardo, con cinco timbres iguales sin distinción de resultados de largas o breves latinas $(a, e, i, o, u)$. Las cinco vocales cardinales forman también el sistema vocálico del vasco y del español moderno (pero no del castellano medieval, que distinguía entre vocal cerrada, sin diptongación y vocal abierta, con ella). Lo que posiblemente se requiera sea una revisión de los tipos de vocales románicas en la Península Ibérica. Aunque parezcan bien establecidos, pueden ofrecer algunos ejemplos de variantes no canónicas, que ya estudió Dámaso Alonso. ${ }^{20}$ Una observación parecida se aplica al problema de una diptongación descendente de las vocales medias cerradas del latín vulgar, existente, aunque poco documentada, de la que nos ocupamos. ${ }^{21}$ Los textos visigodos no ofrecen por ahora información acerca de la diptongación ascendente de las vocales medias abiertas y la de los textos andalusíes es insegura; pero

18 Max Leopold Wagner, Restos de latinidad en el norte de África, Coimbra, Biblioteca da Universidade, 1936.

19 Luca Lorenzetti y Giancarlo Schirru, «Un indizio della conservazione di /k/ dinanzi a vocale anteriore nell'epigrafia cristiana di Tripolitania», en Ignazio Tantillo y Francesca Bigi, Leptis Magna. Una città e le sue iscrizioni in epoca tardoromana, Bonatti, Università degli studi di Cassino, 2010, pp. 303-311.

20 Dámaso Alonso, La fragmentación fonética peninsular, en Enciclopedia Lingüística Hispánica. I. Suplemento, Madrid, Consejo Superior de Investigaciones Científicas, 1962, pp. $23-45$.

21 Francisco Marcos Marín, «La diptongación protohispánica», en Boletín de Filología. Homenaje a Ambrosio Rabanales, 37 (1998-1999), pp. 713-728. 
en inscripciones argelinas se encuentran dieo por deo y uobit quizás por obiit. ${ }^{22}$ Investigadores como Yakov Malkiel también apuntaron algunas peculiaridades que requieren un estudio más al día, con nuevos datos. ${ }^{23}$

En las consonantes, llama la atención el betacismo general del afrorrománico y del vascorrománico, que coincide con ejemplos claros en el latín visigótico y el íbero-romance. No ayudan las transcripciones del árabe, lengua que carece de [v], como el español. Es necesario revisar los desarrollos en romance andalusí y en los préstamos romances en árabe; pero parece muy probable que ese fenómeno diferenciador del castellano frente a las lenguas románicas periféricas de Hispania pueda ofrecer una solución común con los otros dos modelos mencionados, el afrorrománico y el vascorrománico. Otro fenómeno consonántico que llama la atención es la palatalización de [s] final de sílaba. En castellano y aragonés se documenta en transcripciones al árabe de todos los casos de /s/ y contrasta con la solución que el castellano da al grupo árabe [st]. Las transcripciones del latín africano al árabe ofrecen la solución [J], con la letra šīn (ش) en posición final de palabra. Convendría revisar primero las transcripciones de la implosiva -s y luego las de las restantes sibilantes, además de las consonantes implosivas en general.

En lo que se refiere a la lenición, aunque se trate de fechas tempranas y haya que tener en cuenta la influencia de la lengua escrita, el afrorrománico parece alinearse con el italiano en la conservación de las consonantes sordas intervocálicas, salvo cuando van seguidas de [j], porque entonces hay ejemplos de algún tipo de espirantización o quizás de palatalización. Debe tenerse la precaución de no dejarse confundir por la ausencia del fonema /p/ en árabe: caputia > kabudja es un ejemplo claro de lenición y palatalización de $[t+j]$; pero la $-b$ - (ب) en la escritura árabe es inválida como ejemplo gráfico de lenición de /p/. La ausencia de un signo gráfico no significa que los árabes andalusíes o magrebíes no distinguieran o no pudieran usar sonidos como [p]. Simplemente carecían de un signo específico para representarlos.

Los desarrollos morfológicos y sintácticos pueden ser más difíciles de apreciar en el tipo de textos preservados, que requieren un ejercicio más profundo de análisis. Adams, cuyo análisis termina en 600 d. JC, es menos útil en esta área

22 Hubert Petersmann, «Gab es ein afrikanisches Latein? Neue Sichten eines alten Problems der lateinischen Sprachwissenschaft», p. 131.

23 Véanse Malkiel, Yakov, «Towards a Unified System of Classification of Latin-Spanish Vowel Correspondences», en Romance Philology, 16 (1962), pp. 153-169; «Old Spanish Resistance to Diphthongization, or Previous Vowel Lengthening», en Language, 60 (1984), pp. 70-114, y «Spanish Diphthongization and Accentual Structure (in Diachronic Perspective)», en Diachronica, 1 (1984), pp. 217-241. 
que en otras. ${ }^{24}$ Mas se pueden destacar algunas observaciones, cual su indicación de la formación de nuevos tiempos verbales mediante la composición de habeo + participio o su estudio de habeo en la formación del futuro románico. No hace falta aceptar estos fenómenos como soluciones concretas, sino en la perspectiva del cambio de una lengua sintética a otra más analítica.

Siguiendo a Lapesa en su estudio sobre los casos latinos, restos y sustituciones en español, se puede señalar la coincidencia en el latín africano tardío, en el que la simplificación de la declinación es un rasgo bien atestiguado. ${ }^{25} \mathrm{Se}$ reducen y se confunden las formas casuales ${ }^{26}$ y se encuentran ejemplos abundantes en las áreas de interés (Hispania, Italia, Cerdeña y África). Ello permite una aproximación morfológica y sintáctica renovada. Entre los varios ejemplos de nominativo singular usado como caso general, se cita a menudo la Vetus Latina, Lc 1:46 «Magnificat anima mea Dominus», donde Dominus traduce en

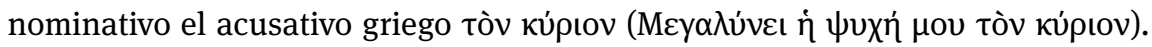
En plural, se documentan formas en -as/-os en inscripciones africanas, al igual que en ítalo-romance, que atestiguan el uso del acusativo como caso general para el plural. El uso del vocativo en lugar del nominativo, también señalado por Petersmann, podría explicar ciertos nombres propios, alguno de ellos relevante, como Jacobe > Yagüe.

Esos datos son consistentes con la presencia de los bereberes, hablantes afrorrománicos, en Alandalús y se relacionan con lo dicho por autores como Oliver Asín. ${ }^{27}$ Es necesaria una cierta precaución como consecuencia natural de la necesidad de revisar lo mucho que se ha escrito acerca de las lenguas románicas y el árabe en Iberia desde una perspectiva acorde con lo que se sabe ahora del árabe y el romance andalusíes. Se debe rechazar lo basado en una interpretación cristiana de Alandalús en su evolución, cuando se intente estudiarla como diferenciada por ello de otras áreas musulmanas. Se olvida que el islam, en el Mediterráneo occidental (además de en otras partes) se asentó sobre una base cristiana previa, incluso más consistente en África que en Hispania. La dependencia de Alandalús de la herencia romana no es diferente de la que se pudo

24 James Noel Adams, Bilingualism and the Latin Language, pp. 501-502, 510, 517 y 717.

25 Rafael Lapesa Melgar, «Los casos latinos: restos sintácticos y sustitutos en español», en Boletín de la Real Academia Española, 44 (1964), pp. 57-106. Véase también al respecto James Noel Adams, Bilingualism and the Latin Language.

26 Véanse también los artículos de James Noel Adams, «The Poets of Bu Njem: Language, Culture and the Centurionate», en The Journal of Roman Studies, 89 (1999), pp. 109-134, y «Latin and Punic in Contact? The Case of the Bu Njem Ostraca», en The Journal of Roman Studies, 84 (1994), pp. 87-112.

27 Jaime Oliver Asín, En torno a los orígenes de Castilla. Su toponimia en relación con los árabes y los beréberes. 
dar en otros reinos musulmanes establecidos sobre territorio que había sido romano. Puede resultar difícil aceptarlo, tras la presión de muchos años de estudiar Alandalús desde una perspectiva europea, diferente de la magrebí; pero la importancia cultural y económica de la Africa provincia y su influencia en Roma fue de mayor peso y profundidad que la de Hispania. La conexión entre ésta y las provincias romanas africanas fue tan profunda que la Tingitana fue, durante un período determinado, parte de la estructura administrativa de Hispania, como una diocesis. Sería muy erróneo tomar esto como indicador de subordinación. El sur y sureste de Hispania dependieron de África tanto o posiblemente más de lo que África dependió de Hispania, por no hablar de la constante relación entre África, Baleares y Tarraconense. La llegada de los hablantes afrorrománicos vinculados a la conquista islámica fue una simple continuación de una conexión que había comenzado casi diez siglos antes.

\section{Obras citadas}

Abaitua Odriozola, Joseba y Mikel Unzueta Portilla, «Ponderación bibliográfica en historiografía lingüística. El caso de la "vasconización tardía”», en Oihenart, 26 (2011), pp. 5-26.

Adams, James Noel, Social Variation and the Latin Language, Cambridge/New York, Cambridge University Press, 2013.

-, Bilingualism and the Latin Language, Cambridge/New York, Cambridge University Press, 2007.

-, The Regional Diversification of Latin $200 B C-A D$ 600, Cambridge/New York, Cambridge University Press, 2003.

-, «The Poets of Bu Njem: Language, Culture and the Centurionate», en The Journal of Roman Studies, 89 (1999), pp. 109-134.

-, «Latin and Punic in Contact? The Case of the Bu Njem Ostraca», en The Journal of Roman Studies, 84 (1994), pp. 87-112.

Alonso, Dámaso, La fragmentación fonética peninsular, en Enciclopedia Lingüística Hispánica. I. Suplemento, Madrid, Consejo Superior de Investigaciones Científicas, 1962, pp. 23-45.

Bingen, Jean, et al., Mons Claudianus, Ostraca graeca et latina II, O.Claud. 191 à 416, Cairo, Institut Français d'Archéologie Orientale, 1997.

-, Mons Claudianus, Ostraca graeca et latina II, O.Claud. 1 à 190, Cairo, Institut Français d'Archéologie Orientale, 1992.

Bonnal J. P., y Paul Albert Février, «Ostraka de la région de Bir Trouch», en Bulletin de l'Archéologie Algérienne, 2 (1966-1967), pp. 239-249.

Bülow-Jacobsen, Adam, Mons Claudianus. Ostraca Graeca et Latina IV. The Quarry-Texts (O.Claud. 632-896), Cairo, Institut Français d’Archéologie Orientale, 2009.

Corriente, Federico, A Descriptive and Comparative Grammar of Andalusi Arabic, Leiden/ Boston, Institute of Islamic Studies of the University of Zaragoza/Brill, 2013.

Cuvigny, Hélène, Mons Claudianus. Ostraca Graeca et Latina III. Les reçus pour avances à la familia (O.Claud. 417 à 631), Cairo, Institut Français d'Archéologie Orientale, 2000. 
Gómez-Moreno, Manuel, «Sobre los iberos y su lengua», en Homenaje a Menéndez Pidal, Madrid, Hernando, 1925, vol. 3, pp. 475-499.

González Ollé, Fernando, «Vascones y vascuence. Historia (para romanistas) de una relación», en Revista Iberoamericana de Lingüística, 11 (2016), pp. 35-172.

-, «Navarra, Romania Emersa y ¿Romania Submersa?», en Aemilianense, 1 (2004), pp. 225-270.

Lapesa Melgar, Rafael, «Los casos latinos: restos sintácticos y sustitutos en español», en Boletín de la Real Academia Española, 44 (1964), pp. 57-106.

Lorenzetti, Luca, y Giancarlo Schirru, «Un indizio della conservazione di /k/ dinanzi a vocale anteriore nell'epigrafia cristiana di Tripolitania», en Ignazio Tantillo y Francesca Bigi, Leptis Magna. Una città e le sue iscrizioni in epoca tardoromana, Bonatti, Università degli studi di Cassino, 2010, pp. 303-311.

Malkiel, Yakov, «Old Spanish Resistance to Diphthongization, or Previous Vowel Lengthening», en Language, 60 (1984), pp. 70-114.

-, «Spanish Diphthongization and Accentual Structure (in Diachronic Perspective)», en Diachronica, 1 (1984), pp. 217-241.

-, «Towards a Unified System of Classification of Latin-Spanish Vowel Correspondences», en Romance Philology, 16 (1962), pp. 153-169.

Marcos Marín, Francisco, «La recepción de la literatura latina en Hispania y su repercusión en la literatura hispánica», en Stylos, 25 (2016), pp. 147-169.

-, «Las fronteras del latín africano», en las Actas del X Congreso Internacional Estudios de Frontera, homenaje a Pedro Martínez Montávez, Alcalá la Real 5-6 junio 2015, Alcalá la Real, Diputación provincial de Jaén, 2016, pp. 251-266.

-, «Latín africano, bereber, vándalos y visigodos», en Revista Iberoamericana de Lingüística, 11 (2016), pp. 173-208.

-, «Los posibles contactos africanos del romance andalusí», en Constance Carta, Sarah Finci y Dora Macheva (coords.), «Antes se agotan la mano y la pluma que su historia»/«Magis deficit manus et calamus quam eius hystoria». Homenaje a Carlos Alvar, San Millán de la Cogolla, Cilengua, 2016, vol. 1, pp. 199-216.

-, «Latín, beréber, afrorrománico, iberorrománico y romance andalusí. Interacción, desaparición y pervivencia de lenguas», en Revista Iberoamericana de Lingüística, 10 (2015), pp. 33-91.

-, «Notas sobre los bereberes, el afrorrománico y el romance andalusí», en Hesperia Culturas del Mediterráneo, 19 (2015), pp. 203-221.

-, «La diptongación protohispánica», en Boletín de Filología. Homenaje a Ambrosio Rabanales, 37 (1998-1999), pp. 713-728.

-, «Romance andalusí y mozárabe: dos términos no sinónimos», en Estudios de Lingüística y Filología Españolas. Homenaje a Germán Colón, Madrid, Gredos, 1998, pp. 335-341.

Marichal, Robert, Les Ostraca de Bu Njem, (Libya Antiqua, supplément VII), Tripoli, Grande Jamahira Arabe/Libyenne, 1992.

-, «Les ostraca de Bu Njem», en Comptes rendus des séances de l'Académie des Inscriptions et Belles-Lettres, 123.3 (1979), pp. 436-452.

«North Africa», en Late Antique and Early Medieval Inscriptions, Mark Handley, 2010-2014 (página web) [fecha de consulta: 27-03-2016] <http://handley-inscriptions.webs.com/ northafrica.htm>.

Oliver Asín, Jaime, En torno a los orígenes de Castilla. Su toponimia en relación con los árabes y los beréberes, Madrid, Real Academia de la Historia, 1974. 
-, «En trono a los orígenes de Castilla: su toponimia en relación con los árabes y los beréberes», en Al-Andalus, 38.2 (1973), pp. 319-391.

Petersmann, Hubert, «Gab es ein afrikanisches Latein? Neue Sichten eines alten Problems der lateinischen Sprachwissenschaft», en Benjamín García-Hernández (ed.), Estudios de lingüística latina. Actas del IX Coloquio Internacional de Lingüística Latina, Madrid, Ediciones Clásicas, 1998, pp. 125-136.

Väänänen, Veikko, Étude sur le texte et la langue des Tablettes Albertini, Helsinki, Suomalainen Tiedeakatemia, 1965.

Viguera Molins, María Jesús, «Lengua árabe y lenguas románicas», en Revista de Filología Románica, 19 (2010), pp. 45-54.

Wagner, Max Leopold, Restos de latinidad en el norte de África, Coimbra, Biblioteca da Universidade, 1936.

Zozaya, Juan, «La Bureba ¿frontera islámica mediante colonización agraria?», en Francisco Toro Ceballos y José Rodríguez Molina (coords.), IX Estudios de Frontera. Economía, Derecho y Sociedad en la Frontera. Homenaje a Emilio Molina López, Alcalá la Real, Diputación Provincial de Jaén, 2014, pp. 871-881.

-, «Toponímia (sic) árabe en el valle del Duero», en Mario Jorge Barroca e Isabel Cristina F. Fernandes (eds.), Muçulmanos e Cristãos entre o Tejo e o Douro (Sécs. VIII a XIII). Actas dos Seminários realizados em Palmela, 14 e 15 de Fevereiro de 2003, Porto, 4 e 5 de Abril de 2003, Porto, Câmara Municipal de Palmela/Faculdade de Letras da Universidade do Porto, 2005, pp. 17-42.

-, «La arqueología del poblamiento islámico en Al-Andalus», en Boletín de Arqueología Medieval, 7 (1993), pp. 53-64. 